Document downloaded from:

http://hdl.handle.net/10251/149935

This paper must be cited as:

Pedro-Monzonis, M.; Jiménez Fernández, P.; Solera Solera, A.; Jiménez Gavilán, P. (2016). The use of AQUATOOL DSS applied to the System of Environmental-Economic Accounting for Water (SEEAW). Journal of Hydrology. 533:1-14.

https://doi.org/10.1016/j.jhydrol.2015.11.034

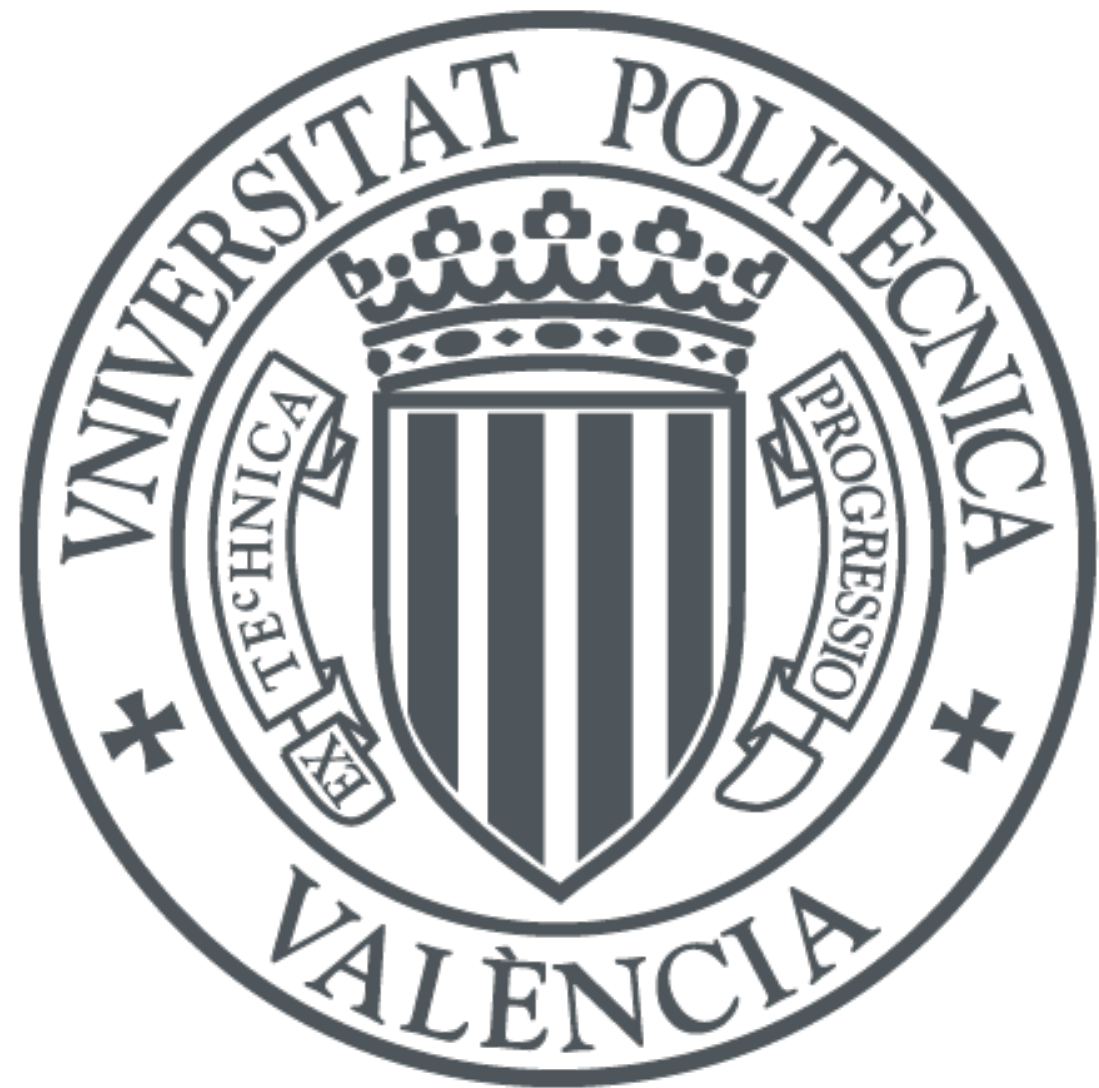

The final publication is available at

https://doi.org/10.1016/j.jhydrol.2015.11.034

Copyright Elsevier

Additional Information 


\title{
The use of AQUATOOL DSS applied to the System of Environmental- Economic Accounting for Water (SEEAW)
}

\author{
María Pedro-Monzonís ${ }^{1 *}$, Pedro Jiménez Fernández ${ }^{2}$, Abel Solera Solera ${ }^{1}$ and Pablo \\ Jiménez Gavilán²
}

${ }^{1}$ Research Institute of Water and Environmental Engineering (IIAMA), Universitat Politècnica de València, Valencia (Spain)

${ }^{2}$ Department of Geology and Centre of Hydrogeology of the University of Malaga (CEHIUMA), University of Málaga, Málaga (Spain)

*mapedmon@upv.es

\begin{abstract}
Currently, water accounts are one of the next steps to be implemented in European River Basin Management Plans. Building water accounts is a complex task, mainly due to the lack of common European definitions and procedures. For their development, when data is not systematically measured, simulation models and estimations are necessary. The main idea of this paper is to present a new approach which enables the combined use of hydrological models and water resources models developed with AQUATOOL Decision Support System (DSS) to fill in the physical water supply and use tables and the asset accounts presented in the System of Economic and Environmental Accounts for Water (SEEAW). The case study is the Vélez River Basin, located in the southern part of the Iberian Peninsula in Spain. In addition to obtaining the physical water supply and use tables and the asset accounts in this river basin, we present here the indicators as a result thereof. These indicators cover many critical aspects of water management, showing a general description of the river basin and allowing decision-makers to characterize the pressures on water resources. As a general conclusion, the union of AQUATOOL DSS and SEEAW will provide more complete information to decision-makers and enables to introduce these methodological decisions in order to guarantee consistency and comparability of the results between different river basins.
\end{abstract}


Keywords: Water accounts, System of Environmental-Economic Accounting for Water (SEEAW), AQUATOOL, water resources systems

\section{Introduction}

One of the main challenges in the XXI century is related with the sustainable use of water. This is due to the fact that water is an essential element for the life of all who inhabit our planet. In many cases, the absence of a rational water use is due to the lack of economic valuation of water resources. To improve this situation, first, the EU Water Framework Directive (WFD) (EP, 2000) established a framework for the Community action in the field of water policy. Its main objectives included expanding the scope of water protection to all waters in order to achieve their "good status", a water management based on river basins, the implementation of pricing policies and the promotion of public participation, among others. The Member States were required to implement the WFD by the river basin management plans, which had to include a description of the river basin, an inventory of water resources and demands, a register of protected areas, the regime of environmental flows, the water exploitation systems and their water balances, an inventory of pressures, the environmental targets, cost recovery, the programme of measures and the public participation. The Blueprint to safeguard Europe's water resources $(E C, 2012)$ represents another turn of the screw towards an improvement in terms of quality and quantity of water resources. The Water Blueprint presents a three-tier strategic approach by improving the implementation of current European Union (EU) water policy; jointly analysing water policy objectives with the economic growth of other economic sectors such as agriculture, fisheries, renewable energy or transport; and improving significant aspects of the WFD related to water efficiency. To this end, water accounts are presented as a tool to achieve the objective of water efficiency. One of the targets of water accounting is, in addition to comparing results between different territories, to measure the contribution of each water user 
to the overall economic value of water resources in order to identify real potential water savings (Ward and Pulido-Velázquez, 2008; Dumont et al., 2013; Tilmant et al., 2015).

Currently, water accounts are one of the next steps to be implemented in the River Basin Management Plans (Hunink, 2014). In order to assess water resources, water accounts, defined by United Nations Statistics Division (UNSD), have become a very powerful tool for improving water management, as they provide a method of organizing and presenting information relating to the physical volumes of water in the environment, water supply and economy (Vardon et al., 2007). As noted by Molden and Sakthivadivel (1999), their methodology is based on a water balance approach where, based on conservation of mass, the sum of inflows must equal the sum of outflows plus any change in storage. The System of Environmental-Economic Accounting for Water (SEEAW) (UNSD, 2012) is displayed as a tool for water allocation which enables the building of water balances in a river basin. The main concern of the SEEAW is to provide a standard approach which allows policymakers to compare results between different territories and periods. But one of the weaknesses of this approach is that environmental requirements are not explicitly considered and, it is worth noting that the introduction of environmental flows may affect the existing uses in the basin. As observed, building water accounts is a complex task, mainly due to the lack of common European definitions and procedures and the difficulty of the collection of the required data. As noted by Tilmant et al. (2015), although the SEEAW is increasingly adopted, there is no unified procedure to establish water accounts, nor there is an agreement on how water accounts must be presented. Dimova et al. (2014) also indicate that although the SEEAW concepts are relatively simple, its implementation requires collecting a variety of data from numerous actors and stakeholders. Due to the difficulty of gauging the components of the hydrological cycle, the use of simulation models has become an essential tool extensively employed in last decades. 
This research is framed within the Water Accounting in a Multi-Catchment District (WAMCD) project, financed by the European Union. Its main goal is the development of water accounts in the Mediterranean Andalusian River Basin District, in Spain. To achieve this goal, the study draws on several modules from AQUATOOL Decision Support System (AQUATOOL DSS) (Andreu et al., 1996), which enables the building of a water cycle simulation model and a water resources management model in order to create a database to assist the building of the physical water supply and use tables and the asset accounts presented in the SEEAW.

\section{Materials and methods}

Water resources systems analysis comprises all the necessary elements to describe a river basin (Pedro-Monzonís et al., 2015a). It consists of the analytical study of the water resources in a river basin in order to help decision makers to identify and choose one alternative from other possible ones. Water planning and the Integrated Water Resources Management (IWRM) represent the best way to achieve this goal.

\subsection{System of Environmental-Economic Accounting for Water (SEEAW)}

The SEEAW has been developed by the UNSD in conjunction with the London Group on Environmental Accounting (UNDS, 2012). Its main objective has been standardizing concepts related to water accounting, providing a conceptual framework for organising economic and hydrological information. In this sense, water accounts generally, and particularly the SEEAW, expect to become a useful tool for helping on the decision-making process on issues of allocating water resources and improving water efficiency.

SEEAW framework considers the flows between the environment and the economy. The inland water resource system is comprised by surface water, groundwater and soil water; in relation to the economy, it is represented by abstractions, imports, exports and returns of the most relevant economic agents (households, the industry involved in the collection, treatment and 
discharge of sewage, the industry involved in the collection, treatment and supply of water to households, industries and the rest of the world and other industries which use water in their production process). SEEAW tables related to water resources are organised in flow accounts or asset accounts according to whether they represent the water flows in physical units within the economy and between environment and the economy, or they measure stocks at the beginning and the end of the accounting period. This is further discussed in section 2.3. The classification of industrial economic activities traditionally used in SEEAW is the International Standard Industrial Classification of All Economic Activities (ISIC) (UN, 2008), although the economic uses could be classified according to the river basin main economic sectors.

\subsection{AQUATOOL Decision Support System Shell}

AQUATOOL (Andreu et al., 1996) is a user-friendly DSS widely employed by Spanish River Basin Authorities, as well as in other countries (e.g., Chile, Italy, Morocco, among others). This DSS consists of several modules allowing the analysis of different approaches in water resources systems. A brief description of the modules used in this research is presented below.

\subsubsection{EVALHID module}

EVALHID (Paredes-Arquiola et al., 2012) is a module for the development of rainfall-runoff models in complex basins and which evaluates the amount of water resources produced. The module consists of several types of models that can be chosen depending on the available data, the complexity of the basin and the user's experience in the development and calibration of hydrological models. All available models are aggregated with semidistributed application at sub-basin scale.

The HBV model (Hydrologiska Byråns Vattenbalans-avdelning) (Bergström and Forsman, 1973) has been used in the case study. It consists of eight parameters and three state variables. The general processes of the version used of HBV model are illustrated in the figure below. This 
includes a module that processes the data of precipitation as rainfall or snow based on the temperature in each time step. Rainfall and melting snow are processed into the soil moisture form where the effective precipitation contributing to runoff is evaluated. The remainder of precipitation contributes to moisture on the ground, which in turn may evaporate if the content of water present within the ground is large enough. The main output of the model is total runoff in the drainage point of the basin, which consists of three components: direct runoff, interflow (fast discharge plus slow discharge) and baseflow (see figure 1). Additional information related with the HBV model can be found in Götzinger and Bárdossy (2007).

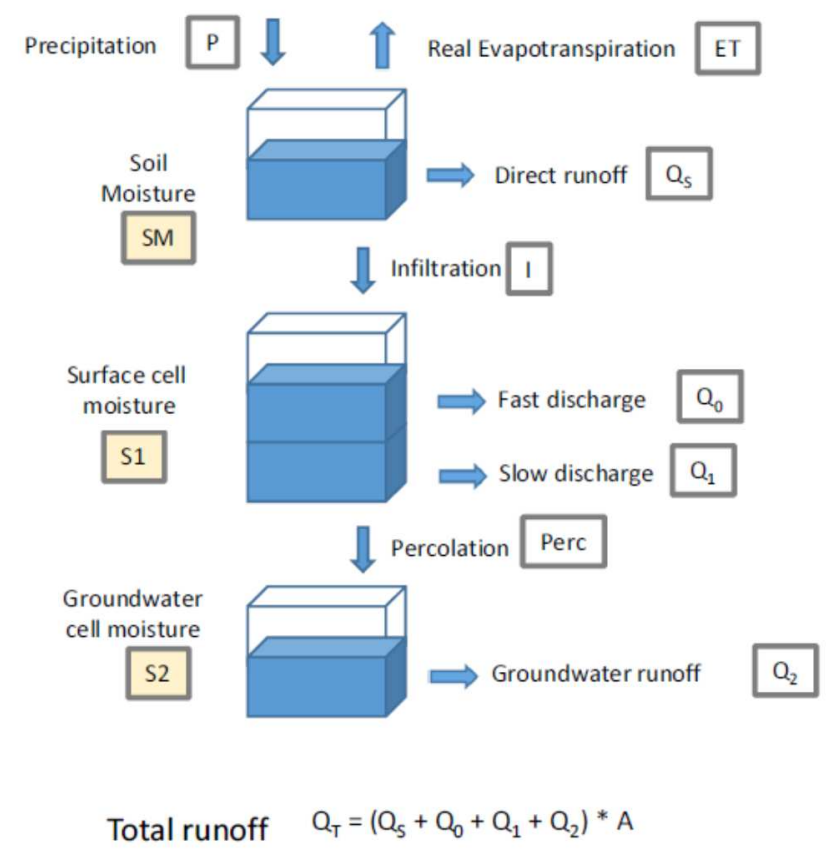

Figure 1. Schematic flow and storage of HBV model

Broadly, the necessary data for each sub-basin are the corresponding area, precipitation $(P)$ and potential evapotranspiration (PET) time series data. The two latter ones have been obtained by using the database of Spain02 (Herrera et al, 2012), which is formed by a rough grating of 20 $\mathrm{km}^{2}$, covering the surface of Spain. This database provide the time series data of maximum and minimum air temperatures and precipitation, both with daily and monthly scale aggregation, for the period 1950-2008. As noted by Vangelis et al. (2013), since precipitation and air temperature 
data are the only readily available data, PET was obtained by the Hargreaves method (Hargreaves and Samani, 1985).

\subsubsection{SIMGES module}

The SIMGES module (Andreu et al., 1996) can simulate the water resources system, on a monthly time scale, by a simple flow balance in a flow network in order to find a flow solution compatible with the defined constraints. It considers the aquifers and the relations between river and aquifer, the returns to the surface system and the infiltration to the groundwater, the evaporation and infiltration loses from reservoirs, the energy production from hydropower stations, the definition of environmental flows as well as different water use priorities. Moreover, the SIMGES module allows us to define operating rules to reproduce source-demand interactions that can help improving integrated river basin management.

\subsection{Combined use of AQUATOOL DSS and SEEAW}

To construct SEEAW tables, we have used a rainfall-runoff model which has been built with EVALHID module. The results are the time series of real evapotranspiration, soil storage, and infiltration, among others. So, once we select the corresponding hydrological year or period of years, we are capable of building SEEAW tables. In order to include the human actions during the planning and management of the water exploitation system, we have used EVALHID results in combination with SIMGES module. The time series of streamflows obtained with EVALHID have been introduced in a SIMGES model, and we obtain results related to water allocation such as water transfers, evaporation in reservoirs, reserves or outflows to the sea, among others, that can be managed by technicians. A scheme of this approach is shown in figure 2 . 


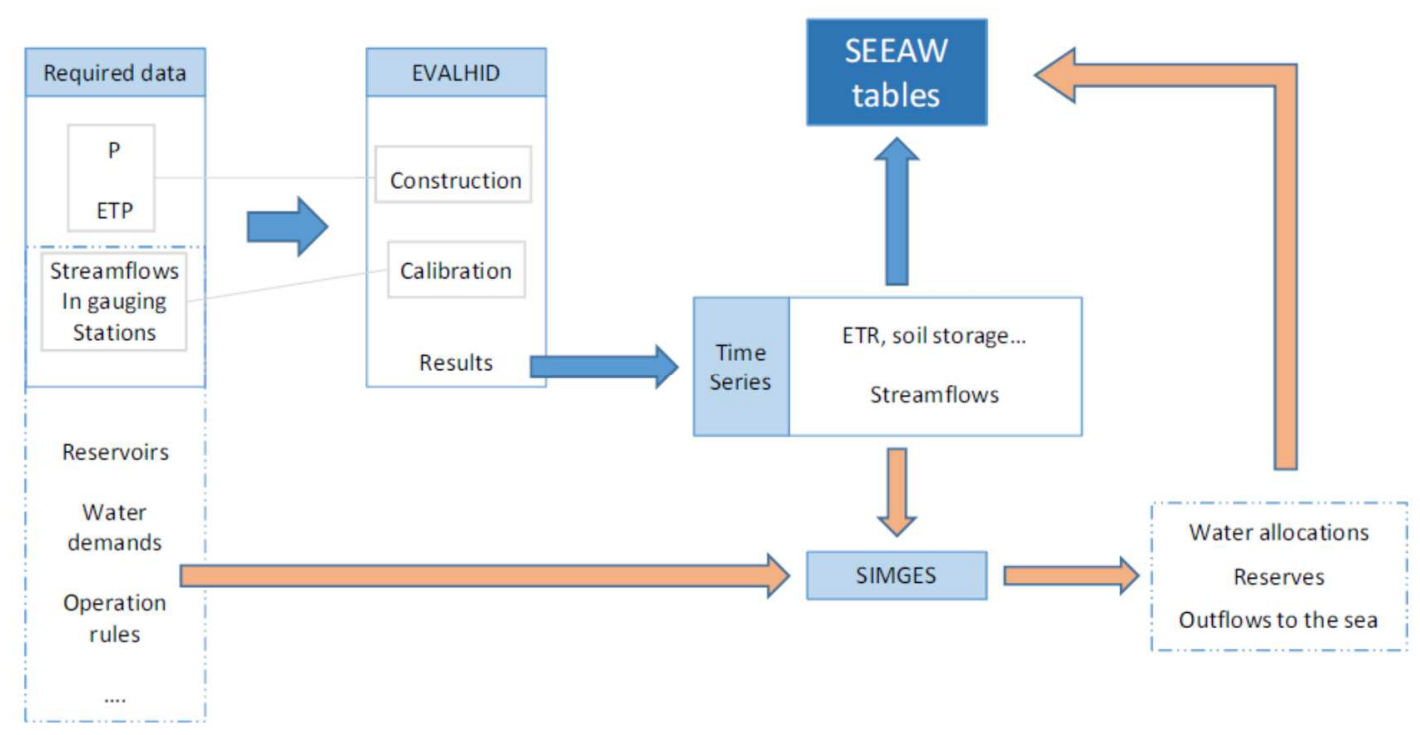

Figure 2. Process to obtain SEEAW tables by using EVALHID and SIMGES tools (Source: EC (2015))

We have developed an acquisition tool consisting of a database linked with SIMGES and EVALHID models, which enables the building of water asset accounts, matrix of flows between water resources and physical water supply and use tables at monthly scale in any month of the simulated period (1950/51-2006/07). Both programs work on a database and their results can also be dumped into the SEEAW database. All data and results are linked with their correspondent element and every element is linked with the type of elements they represent in the system. Note that each element may have several results, e. g. some of the results of a reservoir are volume, evaporation, and filtrations. In order to obtain the accumulated results in the required format of SEEAW tables, it has been necessary the building of several database queries which are linked with several spreadsheets where the tables are finally built.

Water asset accounts (see table 1) measures stocks at the beginning and at the end of the accounting period and record the changes in stocks that occur during that period due to natural causes (precipitation, evapotranspiration) and human activities (abstractions, returns). On the other hand, matrix of flows (see table 2) describes exchanges of water between water resources, providing information on the origin and destination of flows in the territory. It assists in identifying the contribution of groundwater to the surface flow as well as the recharge of 
aquifers by surface runoff. In both tables, the source information of each cell may come from

EVALHID and/or SIMGES models.

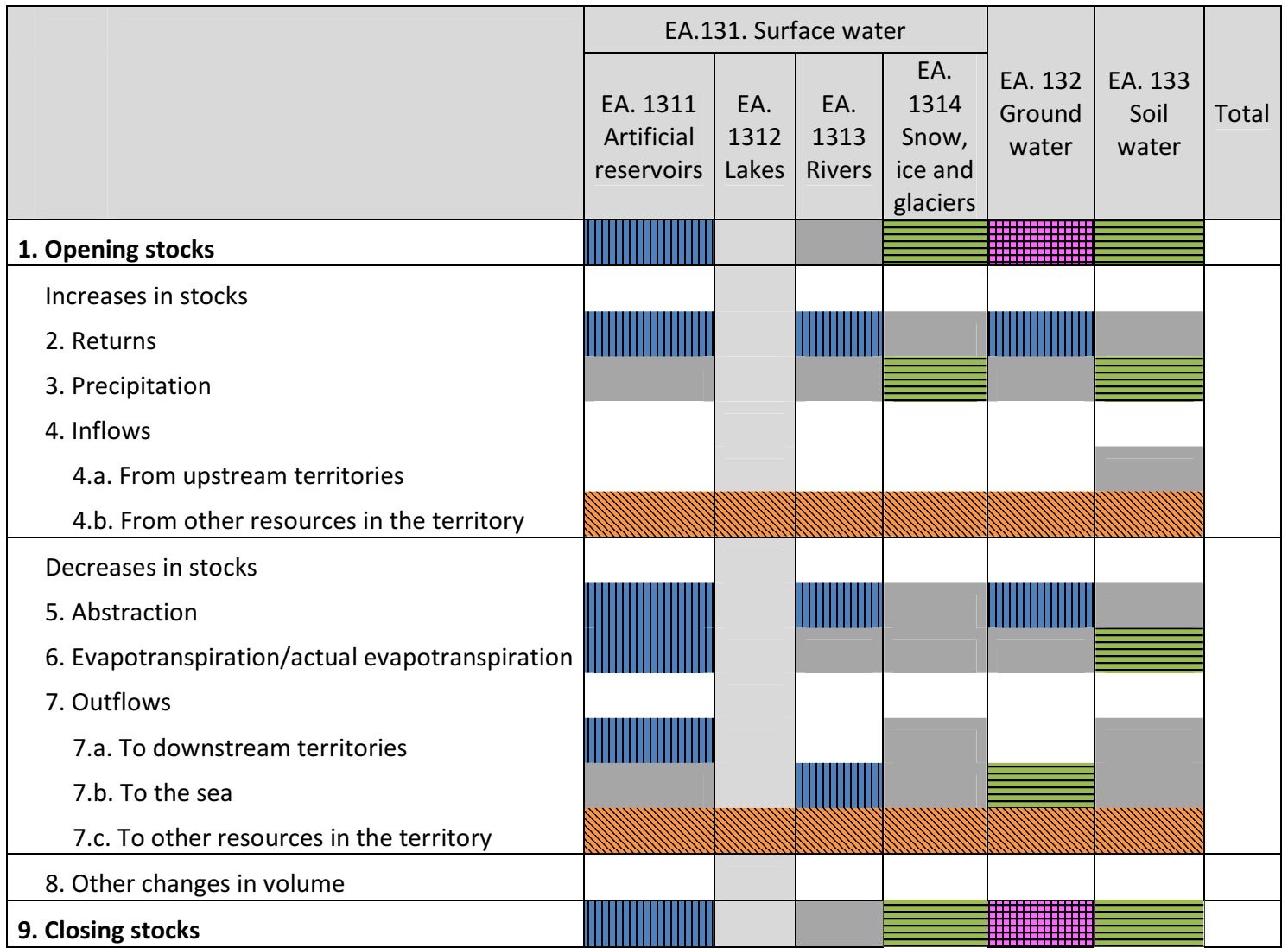

Table 1. Water asset accounts $\left(\mathrm{hm}^{3}\right)$ [Blue cells with an horizontal pattern style indicate these data come from

SIMGES model, green cells with a vertical pattern style indicate these data come from EVALHID model, pink cells with a grid pattern style indicate these data come from EVALHID and SIMGES models. Orange cells with sloped pattern style indicate these data come from the matrix of flows between water resources table.]

\begin{tabular}{|c|c|c|c|c|c|c|c|}
\hline & \multicolumn{4}{|c|}{ EA.131. Surface water } & \multirow[b]{2}{*}{$\begin{array}{c}\text { EA. } 132 \\
\text { Ground } \\
\text { water }\end{array}$} & \multirow[b]{2}{*}{$\begin{array}{l}\text { EA. } \\
133 \\
\text { Soil } \\
\text { water }\end{array}$} & \multirow[b]{2}{*}{$\begin{array}{l}\text { Outflows } \\
\text { to other } \\
\text { resources } \\
\text { in the } \\
\text { territory }\end{array}$} \\
\hline & $\begin{array}{l}\text { EA. } 1311 \\
\text { Artificial } \\
\text { reservoirs }\end{array}$ & $\begin{array}{c}\text { EA. } \\
1312 \\
\text { Lakes }\end{array}$ & $\begin{array}{c}\text { EA. } \\
1313 \\
\text { Rivers }\end{array}$ & $\begin{array}{c}\text { EA. } \\
1314 \\
\text { Snow, } \\
\text { ice and } \\
\text { glaciers }\end{array}$ & & & \\
\hline \multicolumn{8}{|l|}{ EA. 1311 Artificial reservoirs } \\
\hline EA. 1312 Lakes & & & & & & & \\
\hline EA. 1313 Rivers & & & & & & & \\
\hline EA. 1314 Snow, ice and glaciers & & & & & & & \\
\hline EA. 132 Groundwater & & & 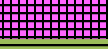 & & & & \\
\hline EA. 133 Soil water & & & & & & & \\
\hline
\end{tabular}


Table 2. Matrix of flows between water resources $\left(\mathrm{hm}^{3}\right)$ [Blue cells with an horizontal pattern style indicate these data come from SIMGES model, green cells with a vertical pattern style indicate these data come from EVALHID model, pink cells with a grid pattern style indicate these data come from EVALHID and SIMGES models. Orange cells with sloped pattern style indicate these results are used in water asset accounts table.]

The physical use table is divided into two parts: the first part describes flows from the environment to the economy (such as water abstraction) and the second part describes flows within the economy (such as water received from other economic units). Likewise, the physical supply table is also divided into two parts: the first part describes the flows of water within the economy (such as the supply of water to other economic units) and the second part describes flows from the economy to the environment (such as returns of water into the environment). These are the classification of the economic water uses in these tables: urban, farming, cattle raising, recreational and rest of the world. This classification differs from the ISIC (UN, 2008) and is adapted to the main economic features of the river basin, where agrarian and touristic uses are the principal ones. Note that each cell in physical use and supply tables comes from SIMGES model.

\section{Case study: The Vélez River Basin}

\subsection{Characterization of the study area}

The Vélez River Basin is located in the southern part of the Iberian Peninsula in Spain (see figure 3). This river basin is managed by the Mediterranean Andalusian Basin' River Basin District (MAB RBD) which includes up to 16 subsystems (or exploitation systems). The Vélez River is included in the sub-system II.1 and it has a length of $68 \mathrm{~km}$, traversing the province of Malaga. Its main tributaries are Benamargosa, Guaro, Alcaucín, Bermuza, Almanchares and Rubite rivers. The climate is subtropical Mediterranean with an average precipitation of $630 \mathrm{~mm} / \mathrm{year}$, and an average temperature of $16^{\circ} \mathrm{C}$. There is a progressive transition to a maritime Mediterranean climate as we move up to the peaks further north (García-Aróstegui et al, 2007). The hydrological 
regime is determined by the artificial reservoir of La Viñuela, which was completed in the midnineties of the last century. This system includes La Viñuela reservoir (with a capacity of 173 $\mathrm{hm}^{3}$ ) and eight diversion dams to transfer the surplus flows of the basin to the reservoir. These reserves are assigned to the supply of agrarian and urban demands. In the final part of the Vélez River Basin is located the Río Vélez-060.026 groundwater body (Río Vélez GWB in figure 3). This GWB is comprised of a single detrital aquifer made up of Quaternary deltaic and alluvial sediments with an average thickness of $30 \mathrm{~m}$ which reaches maximums of approximately $60 \mathrm{~m}$ in the central part-confluence of the Vélez and Benamargosa rivers-and in the deltaic sector (Benavente et al, 2005). The hydrogeological behaviour of Río Vélez GWB is conditioned by La Viñuela Reservoir and the diversion dams, since they affect the recharge of the aquifer, and reduce considerably the vertical aquifer thickness $(6 \mathrm{~m})$, at $4 \mathrm{~km}$ from the coast, dividing the aquifer into a fluvial sector upstream and a coastal (deltaic) sector downstream (Benavente et al, 2005). When an important period of groundwater exploitation occurs, this latter feature can be advantageous, from a hydrogeological point of view, as it inhibits the saltwater wedge from intruding inland (Lentini et al, 2009).

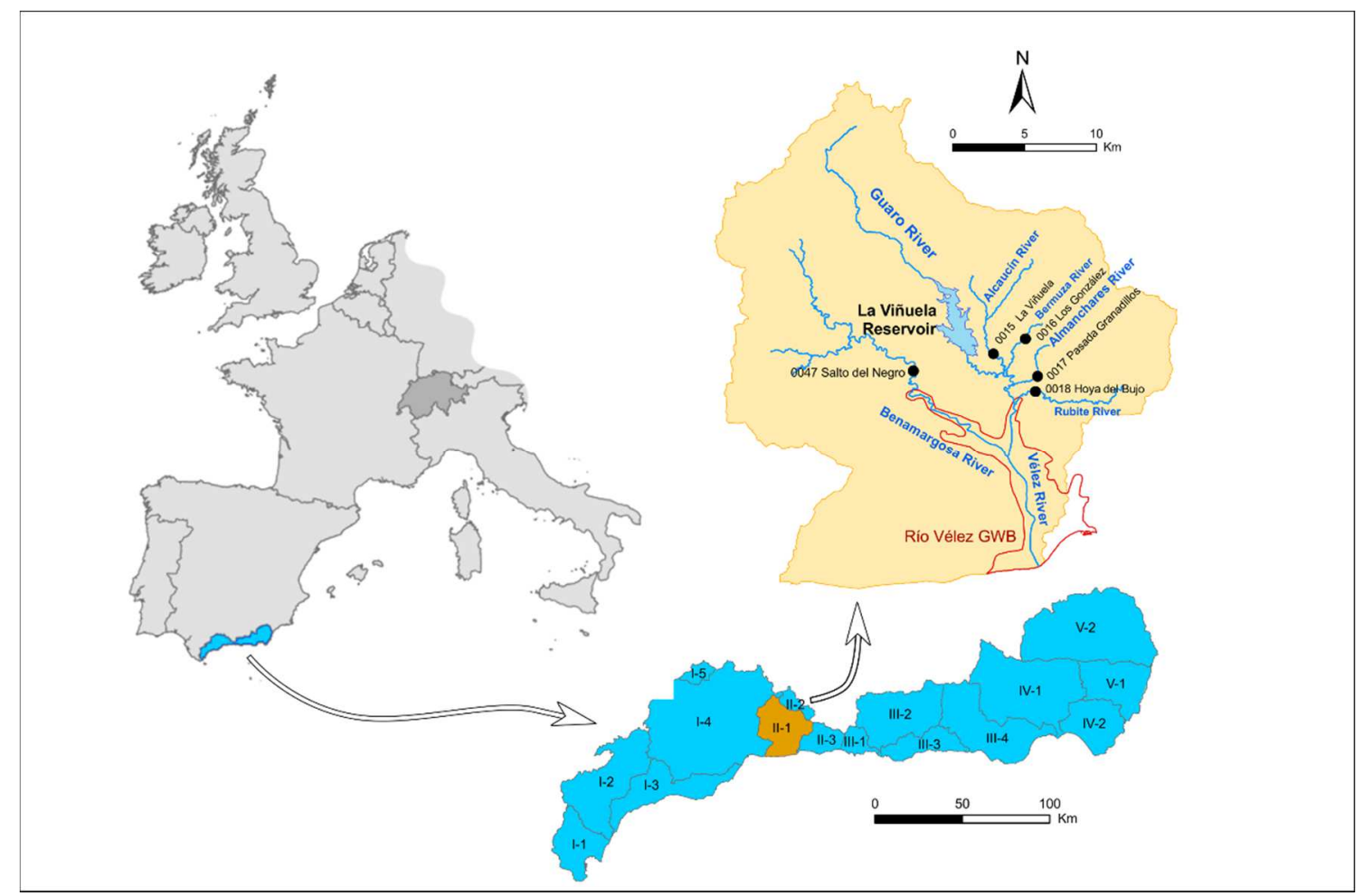




\subsection{Modelling the Vélez River Basin by using AQUATOOL DSS}

The first step for modelling the Vélez River Basin is the obtention of the streamflow data series from the rainfall-runoff model. The election of the calibration points has been determined by the availability and length of records in gauging stations and reservoirs. It was performed in 6 points of the Vélez system: La Viñuela Reservoir, EA 0015 La Viñuela, EA 0016 Los González, EA 0017 Pasasda Granadillos, EA 0018 Hoya del Bujo and EA 0047 Salto del Negro. Each of these gauging stations is located in the tributaries of the Vélez River. With regard to the time period used for calibration, we have reserved the first two hydrological years as warm-up period to minimize the effect of initial moisture conditions, and the last three available years are used for validation. Furthermore, the calibration period finishes in 1992 when several transfers started operation in the basin, so the alteration of gauging stations became obvious. A Visual Basic adaptation to the SCE-UA algorithm (Duan et al., 1992) has been used to import the results from EVALHID streamflows to compare with the series of observed inputs and evaluate an objective function that represents a numerical measure of the difference between the simulated response of the model and the response observed in the basin. The degree of adjustement between the observed values and the simulated ones is measured by a graphic display and the use of objective functions whose minimization is the foundation of techniques of automatic calibration parameters. The objective function used is the average of the following functions: Nash-Sutcliffe index, Nash Neperian logarithm, Pearson correlation coefficient and Average of the symmetry of the adjustement between average simulation and average observation.

Once the streamflow data series have been obtained, the next step is to introduce them in the water resources management simulation model with all the required data related to reservoirs, water demands, operation rules and environmental requirements. The latter are included as minimum flows and they are based on habitat modelling assessment, hydrological criteria and 
expert recommendations for the saturation of the alluvial aquifer. Figure 4 shows the scheme of the simulation model that has been built for the current scenario with SIMGES module. This model reflects the complex interaction among all elements in the system.

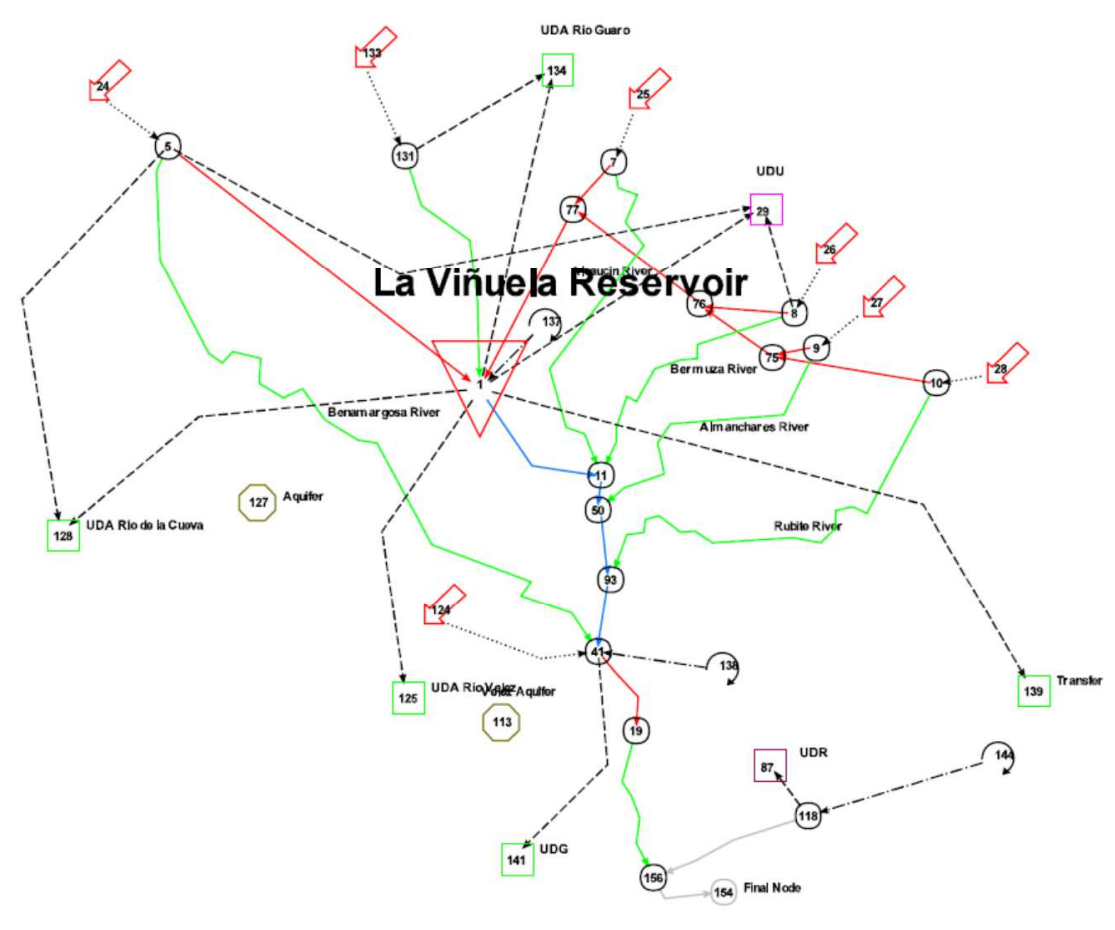

AQUATOOL

Figure 4. Scheme of the simulation model of Vélez River Basin [UDA means farming demand; UDU means urban demand; UDR means recreational demand and UDG means cattle raising demand]

\section{Results}

\subsection{Results from EVALHID module}

EVALHID results have allowed us, on the one hand, to obtain the streamflow data series which will be used in the SIMGES model and, on the other hand, to fill in the SEEAW tables that information related to the components of the hydrological cycle which cannot be physically measured. The latter include actual evapotranspiration (ET), soil storage, infiltration to aquifers (Inf), discharge from soil to surface waters (Groundwater runoff) and discharge from aquifers to surface waters (Surface runoff). Figure 5 shows the average value of the main components of 
the water cycle in the average year of the period 1980/81-2006/07. As it is shown, Vélez River Basin presents warm winters and hot, dry summers; PET increases during harvest months, just when P is lower. Therefore, ET will depend on the availability of water in the basin. Table 3 shows the main statistics for each streamflow element which will be used in the simulation model.

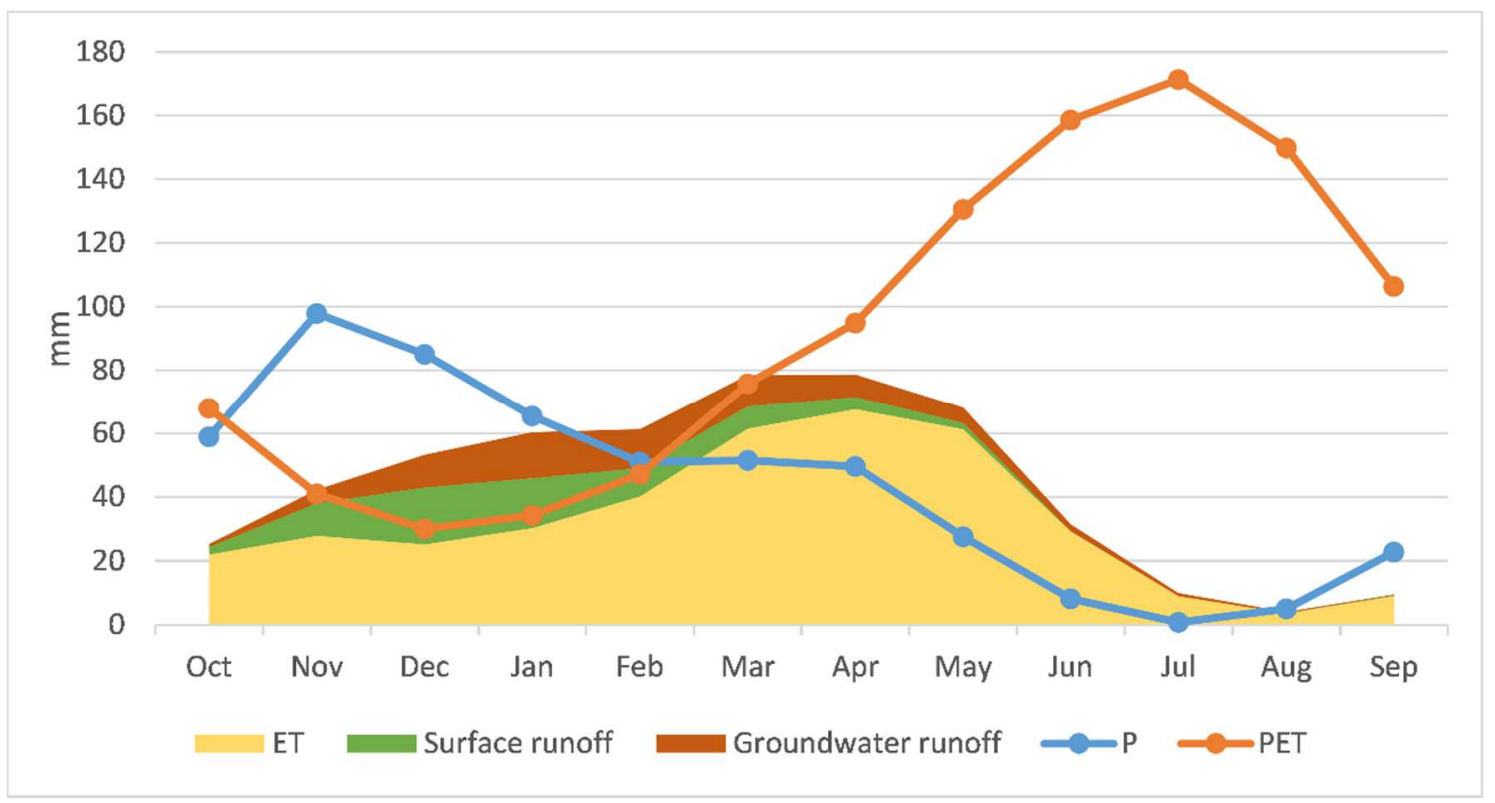

Figure 5. Representation of inputs and outputs of the EVALHID model for the Vélez River Basin (period 1980/81-

2006/07)

\begin{tabular}{|c|c|c|c|c|c|c|c|c|c|c|c|c|c|}
\hline \multicolumn{14}{|c|}{ La Viñuela Streamflow } \\
\hline Statistic & Oct & Nov & Dec & Jan & Feb & Mar & Apr & May & Jun & Jul & Aug & Sep & TOTAL \\
\hline Average & 0.9 & 4.1 & 6.6 & 5.8 & 3.6 & 3.0 & 1.6 & 0.9 & 0.2 & 0.0 & 0.0 & 0.0 & 26.7 \\
\hline Standard deviation (SD) & 2.0 & 5.0 & 9.0 & 9.3 & 4.9 & 3.6 & 2.3 & 1.4 & 0.3 & 0.1 & 0.0 & 0.1 & 23.0 \\
\hline Coeficient of Variation (\%) & 2.3 & 1.2 & 1.4 & 1.6 & 1.4 & 1.2 & 1.4 & 1.6 & 1.5 & 1.4 & 1.4 & 3.9 & 0.9 \\
\hline Bias & 3.0 & 1.1 & 2.0 & 2.2 & 1.8 & 1.6 & 3.3 & 2.2 & 1.9 & 1.8 & 1.6 & 5.0 & 1.1 \\
\hline Median & 0.0 & 1.5 & 2.5 & 1.9 & 1.8 & 1.8 & 0.8 & 0.3 & 0.1 & 0.0 & 0.0 & 0.0 & 22.2 \\
\hline \multicolumn{14}{|c|}{ Salia Streamflow } \\
\hline Statistic & Oct & Nov & Dec & Jan & Feb & Mar & Apr & May & Jun & Jul & Aug & Sep & TOTAL \\
\hline Average & 0.0 & 0.3 & 1.1 & 1.5 & 1.3 & 0.9 & 0.6 & 0.4 & 0.1 & 0.0 & 0.0 & 0.0 & 6.3 \\
\hline Standard deviation (SD) & 0.1 & 0.4 & 2.1 & 3.2 & 2.0 & 1.0 & 1.0 & 0.7 & 0.2 & 0.0 & 0.0 & 0.0 & 8.0 \\
\hline Coeficient of Variation (\%) & 2.4 & 1.3 & 1.9 & 2.1 & 1.6 & 1.1 & 1.5 & 1.7 & 1.6 & 1.5 & 1.5 & 2.1 & 1.3 \\
\hline Bias & 3.9 & 1.7 & 2.4 & 3.5 & 2.2 & 1.7 & 3.6 & 2.9 & 2.6 & 2.5 & 2.5 & 4.1 & 1.7 \\
\hline Median & 0.0 & 0.1 & 0.2 & 0.2 & 0.3 & 0.7 & 0.4 & 0.1 & 0.0 & 0.0 & 0.0 & 0.0 & 2.6 \\
\hline \multicolumn{14}{|c|}{ Bermuza Streamflow } \\
\hline Statistic & Oct & Nov & Dec & Jan & Feb & Mar & Apr & May & Jun & Jul & Aug & Sep & TOTAL \\
\hline Average & 0.4 & 0.8 & 0.9 & 0.9 & 0.7 & 0.6 & 0.5 & 0.4 & 0.2 & 0.1 & 0.1 & 0.1 & 5.7 \\
\hline Standard deviation (SD) & 0.4 & 0.8 & 0.9 & 1.0 & 0.6 & 0.4 & 0.4 & 0.3 & 0.1 & 0.1 & 0.0 & 0.1 & 3.3 \\
\hline Coeficient of Variation (\%) & 1.0 & 0.9 & 1.0 & 1.2 & 0.9 & 0.7 & 0.7 & 0.8 & 0.6 & 0.6 & 0.6 & 1.2 & 0.6 \\
\hline Bias & 1.1 & 1.0 & 1.6 & 1.9 & 1.3 & 0.5 & 1.3 & 1.9 & 0.7 & 0.7 & 1.2 & 2.4 & 1.0 \\
\hline Median & 0.2 & 0.5 & 0.5 & 0.6 & 0.5 & 0.6 & 0.5 & 0.3 & 0.2 & 0.1 & 0.1 & 0.1 & 4.1 \\
\hline
\end{tabular}




\begin{tabular}{|c|c|c|c|c|c|c|c|c|c|c|c|c|c|}
\hline Statistic & Oct & Nov & Dec & Jan & Feb & Mar & Apr & May & Jun & Jul & Aug & Sep & TOTAL \\
\hline Average & 0.0 & 0.2 & 0.4 & 0.6 & 0.4 & 0.3 & 0.2 & 0.1 & 0.1 & 0.0 & 0.0 & 0.0 & 2.4 \\
\hline Standard deviation (SD) & 0.1 & 0.3 & 0.7 & 0.8 & 0.6 & 0.3 & 0.2 & 0.2 & 0.1 & 0.0 & 0.0 & 0.0 & 2.5 \\
\hline Coeficient of Variation (\%) & 2.1 & 1.4 & 1.6 & 1.5 & 1.3 & 0.9 & 1.0 & 1.1 & 1.1 & 1.1 & 1.1 & 1.1 & 1.0 \\
\hline Bias & 3.7 & 1.6 & 2.0 & 2.4 & 1.6 & 1.0 & 2.1 & 2.2 & 2.1 & 2.1 & 2.1 & 1.9 & 1.3 \\
\hline Median & 0.0 & 0.1 & 0.1 & 0.2 & 0.1 & 0.3 & 0.2 & 0.1 & 0.0 & 0.0 & 0.0 & 0.0 & 1.2 \\
\hline \multicolumn{14}{|c|}{ Rubite Streamflow } \\
\hline Statistic & Oct & Nov & Dec & Jan & Feb & Mar & Apr & May & Jun & Jul & Aug & Sep & TOTAL \\
\hline Average & 0.2 & 0.7 & 1.3 & 1.4 & 0.9 & 0.7 & 0.5 & 0.3 & 0.0 & 0.0 & 0.0 & 0.0 & 6.2 \\
\hline Standard deviation (SD) & 0.2 & 1.0 & 2.2 & 2.5 & 1.2 & 0.7 & 0.6 & 0.5 & 0.0 & 0.0 & 0.0 & 0.0 & 5.8 \\
\hline Coeficient of Variation (\%) & 1.5 & 1.4 & 1.6 & 1.7 & 1.3 & 1.0 & 1.2 & 1.6 & 1.1 & 1.1 & 1.1 & 2.5 & 0.9 \\
\hline Bias & 2.4 & 2.3 & 2.3 & 2.7 & 2.2 & 1.0 & 1.9 & 2.5 & 1.2 & 1.5 & 1.6 & 3.5 & 1.3 \\
\hline Median & 0.0 & 0.4 & 0.4 & 0.4 & 0.5 & 0.3 & 0.3 & 0.1 & 0.0 & 0.0 & 0.0 & 0.0 & 3.2 \\
\hline \multicolumn{14}{|c|}{ Benamargosa Streamflow } \\
\hline Statistic & Oct & Nov & Dec & Jan & Feb & Mar & Apr & May & Jun & Jul & Aug & Sep & TOTAL \\
\hline Average & 0.5 & 2.2 & 5.7 & 6.7 & 5.0 & 4.1 & 2.7 & 1.7 & 0.6 & 0.3 & 0.1 & 0.1 & 29.8 \\
\hline Standard deviation (SD) & 0.8 & 3.1 & 10.1 & 11.7 & 7.3 & 4.6 & 3.6 & 2.7 & 0.8 & 0.4 & 0.2 & 0.2 & 35.3 \\
\hline Coeficient of Variation (\%) & 1.7 & 1.4 & 1.8 & 1.7 & 1.5 & 1.1 & 1.3 & 1.5 & 1.3 & 1.3 & 1.3 & 1.6 & 1.2 \\
\hline Bias & 2.6 & 2.8 & 2.4 & 2.6 & 2.3 & 2.1 & 3.2 & 3.0 & 2.9 & 3.0 & 2.9 & 3.2 & 1.5 \\
\hline Median & 0.1 & 1.0 & 1.5 & 1.9 & 2.1 & 3.3 & 1.7 & 0.9 & 0.4 & 0.2 & 0.1 & 0.1 & 13.1 \\
\hline \multicolumn{14}{|c|}{ Guaro Final Stretch Streamflow } \\
\hline Statistic & Oct & Nov & Dec & Jan & Feb & Mar & Apr & May & Jun & Jul & Aug & Sep & TOTAL \\
\hline Average & 0.1 & 0.5 & 1.2 & 1.4 & 1.0 & 0.8 & 0.5 & 0.3 & 0.1 & 0.1 & 0.0 & 0.0 & 6.2 \\
\hline Standard deviation (SD) & 0.2 & 0.8 & 2.3 & 2.6 & 1.6 & 0.9 & 0.7 & 0.5 & 0.2 & 0.1 & 0.0 & 0.0 & 7.5 \\
\hline Coeficient of Variation (\%) & 1.9 & 1.7 & 1.9 & 1.8 & 1.5 & 1.1 & 1.3 & 1.5 & 1.3 & 1.3 & 1.3 & 1.9 & 1.2 \\
\hline Bias & 3.3 & 3.2 & 2.6 & 2.8 & 2.4 & 1.7 & 2.8 & 2.8 & 2.4 & 2.5 & 2.5 & 3.9 & 1.5 \\
\hline Median & 0.0 & 0.2 & 0.2 & 0.5 & 0.4 & 0.6 & 0.3 & 0.2 & 0.1 & 0.0 & 0.0 & 0.0 & 2.6 \\
\hline
\end{tabular}

Table 3. Main statistics of the streamflow data series included in SIMGES model ( $\left.\mathrm{hm}^{3}\right)$

The streamflows obtained from EVALHID module have been compared with the results of SIMPA model (Ruiz, 1998) which has been widely generalized in almost all river basin districts in Spain, and also with the respective gauging stations located along the river basin. These gauging stations are integrated in the gauging stations official network (ROEA, for its acronym in Spanish). The SIMPA model is a distributed hydrological model used for the evaluation of water resources in natural regime. It was developed by the Centre for Public Works Studies and Experimentation (CEDEX) during the drafting of the White Paper on Water in Spain (MMA, 2000). As observed in figure 6, generally the results obtained with EVALHID model present a better adjustment than the ones obtained with SIMPA model. The main reason is that EVALHID model is calibrated with more detail in all the gauging stations located in the system, so it allows obtaining a better adjustment especially in headwaters flows. The average year represented in figure 6 has been used for the calibration period. 

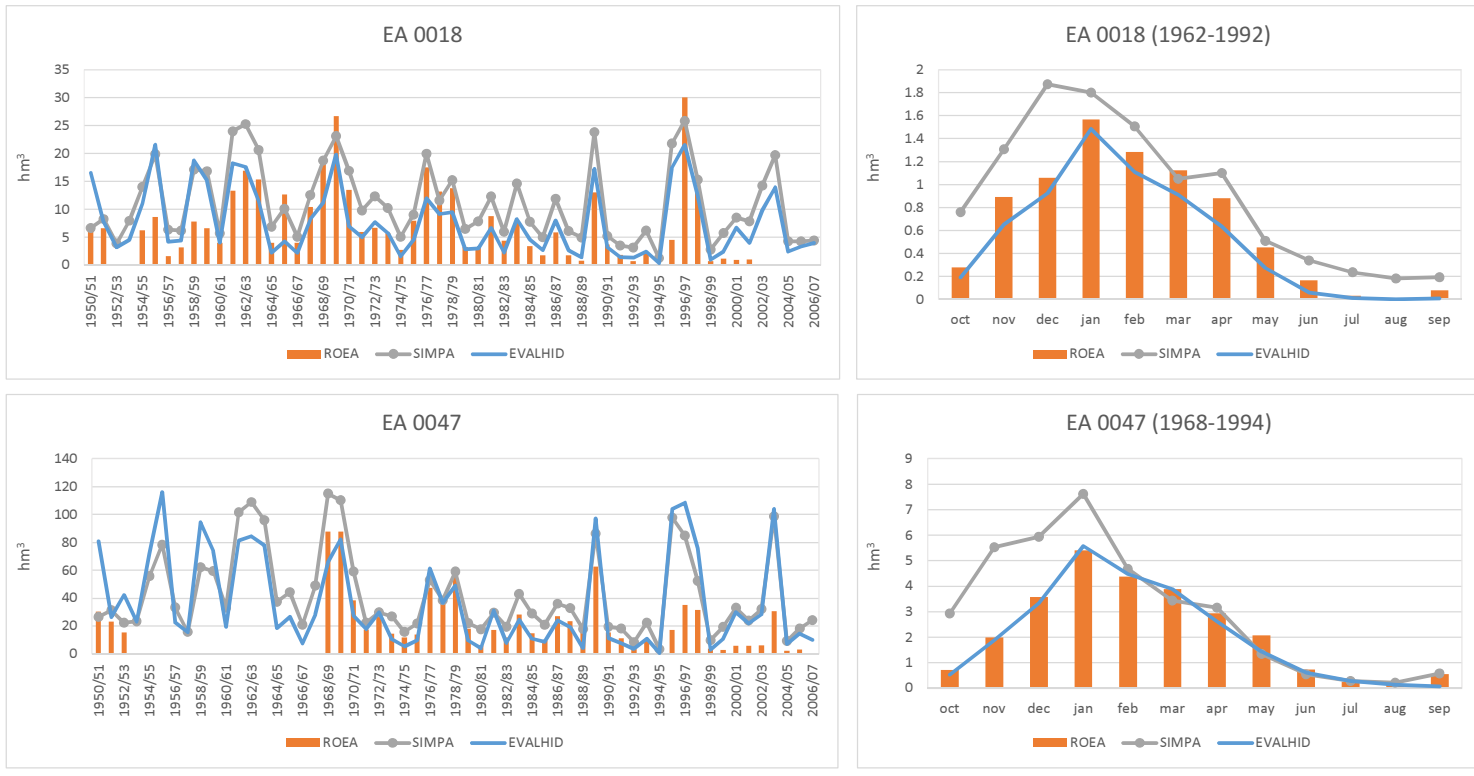

Figure 6. Comparison between EVALHID and SIMPA results with the flows registered in the gauging stations EA 0018 and EA $0047\left(\mathrm{hm}^{3}\right)$ (ROEA means gauging stations official network)

\subsection{Filling in the SEEAW tables}

One of the main objectives of the water accounting is to compare hydrological information not only at spatial dimension, but also at temporal scale. As an example of the applicability of SEEAW approach, the following tables show the water accounts tables in May 1995 and January 1996 in the case study considered. The period 1991-1995 has gone down in history as the worst drought in recent times in Spain. The month of May 1995 represents the beginning of the irrigation season in a long dry period and, on the other hand, the month of January 1996 represents one of the first few months of drought recovery. In this way, we may compare the hydrological cycle processes and the use of water in two different situations, a severe dry period and a wet period.

\subsubsection{Water accounts tables in May 1995}

As we observe in tables 4 and 5 , as a result of the drought period the volume of reserves is zero and precipitation is very low. Similarly, there is a small amount of soil water and it is mainly used in the evapotranspiration process. As the reservoir is empty, the evaporation is zero. There is an 
small amount of water $\left(0.01 \mathrm{hm}^{3}\right)$ that is used in downstream territories. Closing stocks are fewer than opening stocks, and as it is shown, the volume abstracted for water uses comes from La Viñuela reservoir and the intakes located in the river. The negative values of groundwater volumes at opening and closing stocks are explained by the principle of superposition (Reilly et al., 1984; Solera et al., 2010). This means that, as we do not know the volume of water stored in an aquifer, it is assumed that in natural system this volume is zero. So, any action on the aquifer caused by human activities has an effect on the piezometric levels and on its reserves. A negative value indicates a decrease in the volume of water stored in the aquifer, and a positive value indicates an increase. The main exchanges of flows between water resources are those between rivers to La Viñuela reservoir and, outflows from groundwater to river, reducing the amount of water stored in aquifers.

\begin{tabular}{|c|c|c|c|c|c|c|c|}
\hline & \multicolumn{4}{|c|}{ EA.131. Surface water } & \multirow[b]{2}{*}{$\begin{array}{l}\text { EA. } 132 \\
\text { Ground } \\
\text { water }\end{array}$} & \multirow[b]{2}{*}{$\begin{array}{c}\text { EA. } 133 \\
\text { Soil } \\
\text { water }\end{array}$} & \multirow[b]{2}{*}{ Tota } \\
\hline & $\begin{array}{c}\text { EA. } 1311 \\
\text { Artificial } \\
\text { reservoir } \\
\mathrm{s}\end{array}$ & $\begin{array}{c}\text { EA. } 1312 \\
\text { Lakes }\end{array}$ & $\begin{array}{c}\text { EA. } 1313 \\
\text { Rivers }\end{array}$ & $\begin{array}{l}\text { EA. } 1314 \\
\text { Snow, } \\
\text { ice and } \\
\text { glaciers }\end{array}$ & & & \\
\hline 1. Opening stocks & 0.00 & 0.00 & & 0.00 & -0.38 & 8.77 & 8.39 \\
\hline Increases in stocks & \multirow{3}{*}{0.00} & & \multirow[b]{2}{*}{0.04} & & \multirow{3}{*}{0.00} & & \multirow{3}{*}{$\begin{array}{l}0.04 \\
0.36\end{array}$} \\
\hline 2. Returns & & & & & & & \\
\hline 3. Precipitation & & & & & & 0.36 & \\
\hline 4. Inflows & \multirow[t]{2}{*}{0.03} & & \multirow[t]{2}{*}{0.06} & & \multirow[t]{2}{*}{0.00} & \multirow[t]{2}{*}{0.00} & \multirow{3}{*}{$\begin{array}{l}0.09 \\
0.00 \\
0.09\end{array}$} \\
\hline 4.a. From upstream territories & & & & & & & \\
\hline 4.b. From other resources in the territory & 0.03 & 0.00 & 0.06 & 0.00 & 0.00 & 0.00 & \\
\hline Decreases in stocks & \multirow{5}{*}{$\begin{array}{l}0.00 \\
0.01 \\
0.01\end{array}$} & \multirow[b]{7}{*}{0.00} & \multirow{3}{*}{0.07} & & \multirow{3}{*}{0.00} & & \multirow{3}{*}{0.09} \\
\hline 5. Abstraction & & & & & & & \\
\hline $\begin{array}{l}\text { 6. Evapotranspiration/actual } \\
\text { evapotranspiration }\end{array}$ & & & & & & 6.63 & \\
\hline 7. Outflows & & & \multirow[t]{2}{*}{0.03} & & \multirow[t]{3}{*}{0.06} & 0.00 & \multirow{2}{*}{$\begin{array}{l}0.10 \\
0.01\end{array}$} \\
\hline 7.a. To downstream territories & & & & & & & \\
\hline 7.b. To the sea & & & 0.00 & & & & 0.00 \\
\hline 7.c. To other resources in the territory & 0.00 & & 0.03 & 0.00 & 0.06 & 0.00 & 0.09 \\
\hline 8. Other changes in volume & & & & & & & 0.00 \\
\hline 9. Closing stocks & 0.00 & 0.00 & & 0.00 & -0.44 & 2.49 & 2.06 \\
\hline
\end{tabular}

Table 4. Water asset accounts in May $1995\left(\mathrm{hm}^{3}\right)$ 


\begin{tabular}{|c|c|c|c|c|c|c|c|}
\hline & & A.131. Sur & face wate & & & & Outflows \\
\hline & $\begin{array}{c}\text { EA. } 1311 \\
\text { Artificial } \\
\text { reservoirs }\end{array}$ & $\begin{array}{c}\text { EA. } 1312 \\
\text { Lakes }\end{array}$ & $\begin{array}{l}\text { EA. } 1313 \\
\text { Rivers }\end{array}$ & $\begin{array}{c}\text { EA. } 1314 \\
\text { Snow, ice } \\
\text { and } \\
\text { glaciers }\end{array}$ & $\begin{array}{c}\text { EA. } 132 \\
\begin{array}{c}\text { Groundw } \\
\text { ater }\end{array}\end{array}$ & $\begin{array}{c}\text { EA. } 133 \\
\text { Soil } \\
\text { water }\end{array}$ & $\begin{array}{l}\text { to other } \\
\text { resource } \\
\text { s in the } \\
\text { territory }\end{array}$ \\
\hline EA.1311 Artificial reservoirs & & & 0.00 & & 0.00 & & 0.00 \\
\hline EA. 1312 Lakes & & & & & & & \\
\hline EA. 1313 Rivers & 0.03 & & & & 0.00 & & 0.03 \\
\hline EA. 1314 Snow, ice and glaciers & & & & & & & 0.00 \\
\hline EA. 132 Groundwater & & & 0.06 & & & & 0.06 \\
\hline EA. 133 Soil water & & & 0.00 & & 0.00 & & 0.00 \\
\hline $\begin{array}{l}\text { Inflows from other resources in the } \\
\text { territory }\end{array}$ & 0.03 & 0.00 & 0.06 & 0.00 & 0.00 & 0.00 & 0.09 \\
\hline
\end{tabular}

Table 5. Matrix of flows between water resources in May $1995\left(\mathrm{hm}^{3}\right)$

The physical use and supply tables are shown in table 6 . As we observe, the main use is allocated for urban and recreational uses. Water resources employed to supply urban demands come from surface water (reservoirs and rivers) and recreational water uses are supplied by reused water. These results are interesting because the month of May represents the beginning of the harvest period and all the water supplied is assigned to urban demands, with the consequent harm to agrarian sector.

\begin{tabular}{|c|c|c|c|c|c|c|}
\hline & Urban & Farming & $\begin{array}{l}\text { Cattle } \\
\text { raising }\end{array}$ & Recreational & $\begin{array}{l}\text { Rest of } \\
\text { the world }\end{array}$ & Total \\
\hline 1. Total abstraction & 0.05 & & & & 0.01 & 0.06 \\
\hline 1.a Abstraction for own use & 0.05 & & & & 0.01 & 0.06 \\
\hline 1.b Abstraction for distribution & & & & & & \\
\hline 1.i From inland water resources & 0.05 & & & & 0.01 & 0.06 \\
\hline 1.i.1 Surface water & 0.05 & & & & 0.01 & 0.06 \\
\hline 1.i.2 Groundwater & & & & & & \\
\hline 1.i.3 Soil water & & & & & & \\
\hline 1.ii From water resources & & & & & & \\
\hline 1.ii.1 Collection of precipitation & & & & & & \\
\hline 1.ii.2 Abstraction from the sea & & & & & & \\
\hline 2. Use of water received from other economic units & & & & 0.04 & & 0.04 \\
\hline 2.a Reused water & & & & 0.04 & & 0.04 \\
\hline 2.b Wastewater to sewerage & & & & & & \\
\hline 2.c Desalinated water & & & & & & \\
\hline 3. Total use of water & 0.05 & 0.00 & 0.00 & 0.04 & 0.01 & 0.10 \\
\hline 4. Supply of water to other economic units & 0.04 & & & & & 0.04 \\
\hline 4.a Reused water & 0.04 & & & & & 0.04 \\
\hline 4.b Wastewater to sewerage & & & & & & \\
\hline 5. Total returns & & & & & & 0.00 \\
\hline 5.a To water resources & & & & & & \\
\hline 5.a.i Surface water & & & & & & \\
\hline
\end{tabular}




\begin{tabular}{|c|c|c|c|c|c|c|}
\hline $\begin{array}{ll}\text { 5.a.ii Groundwater } \\
\text { 5.a.iii Soil water } \\
\text { 5.b } \text { To other sources }\end{array}$ & & & & & & \\
\hline 6. Total supply of water & 0.04 & & & & & 0.04 \\
\hline $\begin{array}{l}\text { 7. Consumption } \\
\text { 7.a Losses from evaporation } \\
\text { 7.b Losses in distribution not because of leakages }\end{array}$ & 0.01 & 0.00 & 0.00 & 0.04 & 0.01 & 0.06 \\
\hline
\end{tabular}

Table 6. Physical use and supply table in May $1995\left(\mathrm{hm}^{3}\right)$

\subsubsection{Water accounts tables in January 1996}

The situation in January 1996 is very different from the previous one, as observed in table 7. Opening stocks indicates that reservoir is filling up and the soil layer contains certain amount of water. The amount of precipitation and the inflows from other resources in the territory are considerable. Abstractions are higher than during the month of May of 1995 due to water availability - in spite of the fact that harvest period begins in May and water demanded by farming is higher. Evapotranspiration has grown up because the higher water availability in the soil, and the outflows also have increased. As a consequence, closing stocks are higher than opening ones, showing the recovering of the system.

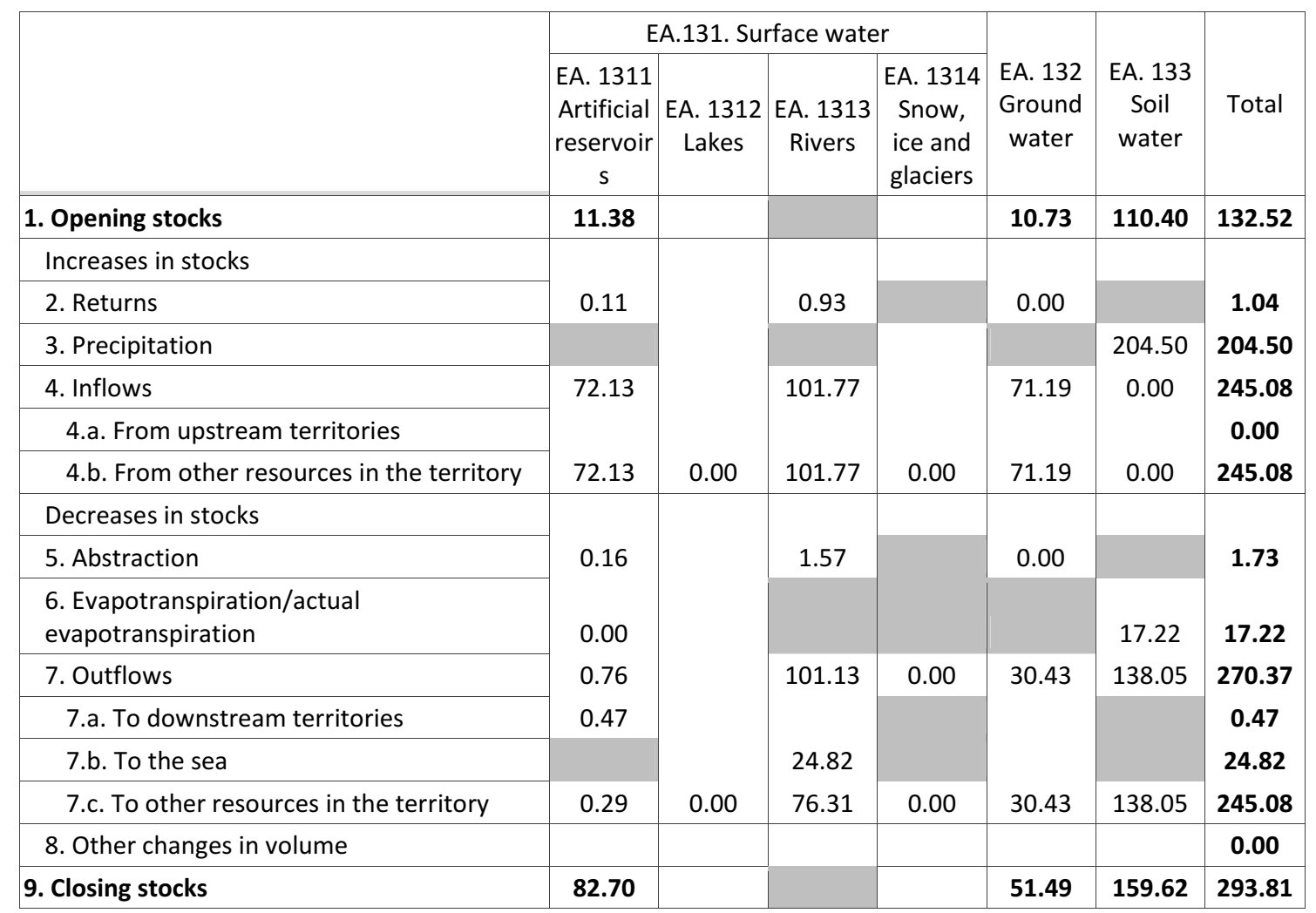


As we observe in table 8, the main flows between water resources are the ones between soil layer with rivers and groundwater, summing up more than $138 \mathrm{hm}^{3}$. As a consequence, the flows from rivers enables an increase of the volume of water stored in reservoirs.

\begin{tabular}{|c|c|c|c|c|c|c|c|}
\hline & & A.131. Sur & face water & & & & Outflows \\
\hline & $\begin{array}{c}\text { EA. } 1311 \\
\text { Artificial } \\
\text { reservoirs }\end{array}$ & $\begin{array}{c}\text { EA. } 1312 \\
\text { Lakes }\end{array}$ & $\begin{array}{l}\text { EA. } 1313 \\
\text { Rivers }\end{array}$ & $\begin{array}{c}\text { EA. } 1314 \\
\text { Snow, ice } \\
\text { and } \\
\text { glaciers }\end{array}$ & $\begin{array}{c}\text { EA. } 132 \\
\text { Groundw } \\
\text { ater }\end{array}$ & $\begin{array}{c}\text { EA. } 133 \\
\text { Soil } \\
\text { water }\end{array}$ & $\begin{array}{l}\text { to other } \\
\text { resource } \\
\text { s in the } \\
\text { territory }\end{array}$ \\
\hline EA.1311 Artificial reservoirs & & & 0.29 & & 0.00 & & 0.29 \\
\hline EA. 1312 Lakes & & & & & & & \\
\hline EA. 1313 Rivers & 72.13 & & & & 4.18 & & 76.31 \\
\hline EA. 1314 Snow, ice and glaciers & & & & & & & 0.00 \\
\hline EA. 132 Groundwater & & & 30.43 & & & & 30.43 \\
\hline EA. 133 Soil water & & & 71.04 & & 67.01 & & 138.05 \\
\hline $\begin{array}{l}\text { Inflows from other resources in the } \\
\text { territory }\end{array}$ & 72.13 & & 101.77 & 0.00 & 71.19 & 0.00 & 245.08 \\
\hline
\end{tabular}

Table 8. Matrix of flows between water resources in January $1996\left(\mathrm{hm}^{3}\right)$

As in the previous balance, abstractions come from surface water as table 9 shows. The main use of water is destined to urban uses and, as in the previous analysis in May of 1995, recreational water uses are supplied by reused water. The water transferred to other territories downstream has been increased in comparison with the month of May.

\begin{tabular}{|c|c|c|c|c|c|c|}
\hline & Urban & Farming & $\begin{array}{l}\text { Cattle } \\
\text { raising }\end{array}$ & Recreational & $\begin{array}{l}\text { Rest of } \\
\text { the world }\end{array}$ & Total \\
\hline 1. Total abstraction & 1.16 & 0.53 & 0.01 & 0.00 & 0.47 & 2.17 \\
\hline 1.a Abstraction for own use & 1.16 & 0.53 & 0.01 & & 0.47 & 2.17 \\
\hline 1.b Abstraction for distribution & & & & & & \\
\hline 1.i From inland water resources & 1.16 & 0.53 & 0.01 & & 0.47 & 2.17 \\
\hline 1.i.1 Surface water & 1.16 & 0.53 & 0.01 & & 0.47 & 2.17 \\
\hline 1.i.2 Groundwater & & & & & & \\
\hline 1.i.3 Soil water & & & & & & \\
\hline 1.ii From water resources & & & & & & \\
\hline 1.ii.1 Collection of precipitation & & & & & & \\
\hline 1.ii.2 Abstraction from the sea & & & & & & \\
\hline 2. Use of water received from other economic units & 0.00 & 0.00 & 0.00 & 0.03 & 0.00 & 0.03 \\
\hline 2.a Reused water & & & & 0.03 & & 0.03 \\
\hline 2.b Wastewater to sewerage & & & & & & \\
\hline 2.c Desalinated water & & & & & & \\
\hline 3. Total use of water & 1.16 & 0.53 & 0.01 & 0.03 & 0.47 & 2.20 \\
\hline 4. Supply of water to other economic units & 0.03 & 0.00 & 0.00 & 0.00 & 0.00 & 0.03 \\
\hline
\end{tabular}




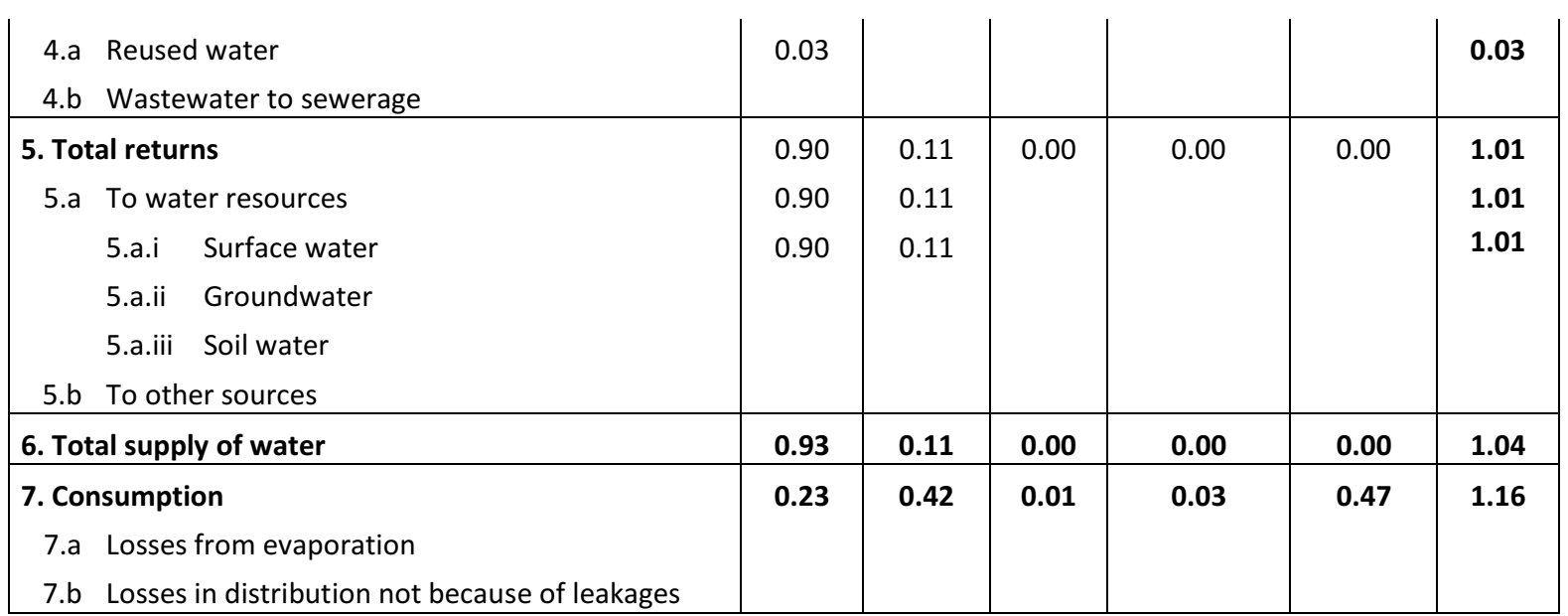

Table 9. Physical use and supply table in January $1996\left(\mathrm{hm}^{3}\right)$

\subsubsection{Discussion on the specific results}

In general terms, as we observe in the tables, variables such as precipitation or evapotranspiration show high volumes of water, while other variables such as abstractions or outflows to the sea, which could be controlled by human actions are one order of magnitude lower than natural processes. This fact is remarkable because variables like precipitation and evapotranspiration cannot be modified during the planning and management of the water exploitation system.

\subsection{Indicators derived from SEEAW tables}

Indicators derived from water accounts show a general description of the river basin with an emphasis on the benefit of natural water and managed water (Pedro-Monzonis et al., 2015b) and allow decision-makers to characterize the pressures on water resources. Some of the indicators defined by United Nations (UNSD, 2012) have been applied in the case study. To show these indicators, we have selected the period 1980/81-2006/07. Internal Renewable Water Resources (IRWR) represents the average annual flow of rivers and recharge of groundwater generated from endogenous precipitation, and it can be obtained from the matrix of flows. For the selected period IRWR are $81.69 \mathrm{hm}^{3} /$ year. On the other hand, External Renewable Water Resources (ERWR) consists of river runoff and groundwater transfers between countries. This 
indicator is obtained from asset accounts. In the case study, for the same period ERWR are 0 $\mathrm{hm}^{3} /$ year, stating that there are not any transfers from other river basins. The sum of IRWR and ERWR correspond to the maximum theoretical amount of water available for a country on an average year on a long reference period. This indicator is named Total Natural Renewable Water Resources (TNRWR) and it is $81.69 \mathrm{hm}^{3} /$ year. When referring to the maximum theoretical amount of water actually available at a given moment, this is named Total Actual Renewable Water Resources (TARWR) and for the month of May of 1995 TARWR $_{\text {May } 95}$ is $0.36 \mathrm{hm}^{3}$ and in January of 1996, TARWR $\mathrm{Jan}_{96}$ is $204.50 \mathrm{hm}^{3}$, both values vary greatly showing the temporal variability of renewable water resources in the basin. From the results above, we have obtained the Dependency ratio $\left(D_{R}\right)$ which expresses the part of the total renewable water resources originating outside the territory and it is obtained as the ratio between ERWR and TNRWR. In the case study $D_{R}$ is $0 \%$. Taking into account the population size, we obtain the renewable resources per capita as the ratio between total renewable water resources and population. In the case study, this is $570 \mathrm{~m}^{3} /$ person. And finally, the density of internal resources (DIR), which is $7.5 \mathrm{hm}^{3} / \mathrm{km}^{2}$, represents the ratio between the average internal flow and the area of the territory. United Nations (UNSD, 2012) also recommend the use of the indicator Exploitable Water Resources (or manageable resources) that represents the part of the water resources which is considered to be available for development under specific, technical, economic and environmental conditions. In this sense, it is not possible to obtain this indicator by employing water accounts. Pedro-Monzonis et al (2015a) propose a methodology for its acquisition.

As can be seen, these indicators are mainly based on the amount of water that is generated in a territory, with special attention to the resources coming from other territories. This kind of indicators may be suitable for international river basins, but the features of those territories are far away from Mediterranean river basins, as we have seen in the case study. On the other hand, the proposed indicators do not refer to the abstractions in the river basin, and they are a crucial fact in order to assess the degree of water stress suffered by water exploitation systems. In this 
sense, Water Exploitation Index (WEI) (EEA, 2005) may help us to know the degree of stress in the river basin. This index is defined as the percentage of mean annual total demand for freshwater with respect to the long-term mean annual freshwater resources and shows to which extent the total water demand puts pressure on water resources. Values of WEI in a river basin between $0 \%$ and $20 \%$ show a situation of no stress; values between $21 \%$ and $40 \%$ indicate water stress; and values upper than $40 \%$ represent extreme water stressed river basins (CIRCABC, 2012). For the period $1980 / 81-2006 / 07$ the WEI in the case study is $73.61 \%$, showing a high degree of water stress in the river basin. Similarly, Water Consumption Index (WCI) (UNDS, 2012) represents the ratio between water consumption and total renewable water resources. In this sense, WEI emphasizes the water abstractions and $\mathrm{WCl}$ is focused on the water consumptions in the river basin, taking into account the use of water returns for other uses downstream. For the period $1980 / 81-2006 / 07$ the $\mathrm{WCl}$ in the case study is $55.84 \%$, softening the degree of stress in the river basin.

On the other hand, we have observed that environmental needs are not explicitly considered in SEEAW tables. Likewise EEA (2013) noted that the ecological requirements represent an important issue and water accounts enable us to obtain a potential indicator of ecological stress for rivers (ESIr) (see Eq. 1):

$E S I_{r}=\frac{\text { outflow }}{\text { outflow }+ \text { abstractions-returns }}$

As ESIr is defined at monthly level, figure 7 represents a cumulative distribution of ESIr in the case study which aggregates the indexes during the analysed period. As noted by EEA (2013) values of ESIr between 0-15\% represent a destructive ecological stress for rivers; between 15$25 \%$ symbolize a non sustainable ecological stress; between $25-50 \%$ represent an excessive ecological stress; between 50-65\% represent a risky ecological stress; between $65-90 \%$ denote a warning ecological stress and finally, ESIr values between $90-100 \%$ show the inexistence of problems in the river. In our case study, the likelihood of having an ESIr less than $25 \%$ (non 
sustainable ecological stress) is approximately $25 \%$, and the likelihood of having an ESIr higher than $90 \%$ without any problem in the river basin is $3 \%$, showing the stress suffered by the system.

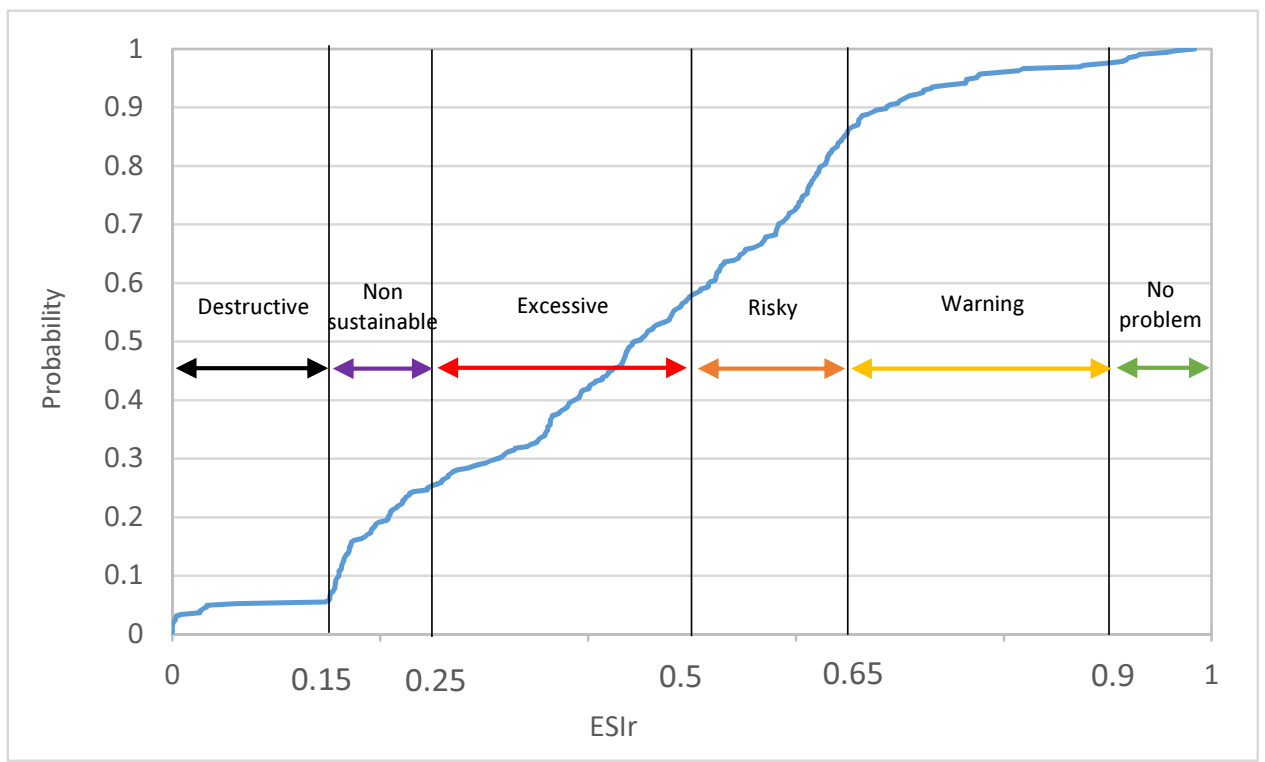

Figure 7. Cumulative distribution function of ESIr (\%) in Vélez River Basin for the period 1980/81-2006/07

\section{Discussion on the applicability of the approach}

As it has been shown in this paper, AQUATOOL DSS represents a reliable tool for building physical and use tables and the asset accounts under the SEEAW methodology, allowing the collection of those parameters of water cycle that cannot be obtained by monitoring. In this sense, AQUATOOL is capable of reproducing the potential evapotranspiration for non-irrigated land, the distinction between surface and groundwater runoff, the amount of soil water, the returns to groundwater and surface water bodies which had not been possible to determine in previous works with WEAP model (Dimova et al., 2014). Even so, there are still some parameters which cannot be reproduced as the losses in distribution networks.

Although SEEAW is the most employed water accounting approach, there are some key issues that are not completely defined or should be better considered. The first handicap is the spatial and temporal aggregation. As regards the spatial consideration, water accounting may be 
developed in different levels of water use. Molden and Sakthivadivel (1999) defined three levels of analysis: macro level (basin or sub-basin level), mezzo level (service level) and micro level (use level). In this way, Momblanch et al. (2014) noted that water management analysis is performed at a water resource system scale, which is conceptually different to the river basin scale. So it may be possible to build SEEAW tables at a river basin scale, at water exploitation system scale or at a local scale. As regards the temporal consideration, traditionally SEEAW tables are built in a natural year concurring with economic accounts but, what about the water exploitation systems with pluriannual regulation?

We have emphasized throughout the paper the relevance of improving water efficiency. Several researches have demonstrated that more efficient irrigation technologies may cause, on the first hand, a decrease in the price of water and, as a consequence, an increase in water global use. On the second hand, they may reduce return flows, affecting downstream users and aquifer recharge. In these circumstances, the improvement in water efficiency can actually increase water depletions. This contradiction is named rebound effect or Jevon's paradox (Dumont et al., 2013). To overcome this situation, designing water pricing policies and the revision of water rights are recommended. Measuring these effects is out of the reach of this paper but some evidence of them can be found in Ward and Pulido-Velazquez (2008) and Gutierrez-Martin and Gomez (2011).

In section 2.3 there are some dark grey cells (see table 1 and table 2 ) which indicate zero entries because two possible reasons: 1) aggregated models do not distinguish between these types of results, such as precipitation on artificial reservoirs, lakes or rivers; 2 ) there are flows between water resources that are physically impossible or unlikely, such as precipitation on groundwater or outflows to the sea from soil water or artificial reservoirs. On the other hand, the column of EA. 1312 Lakes may have the same consideration as the column of EA.1311 Artificial reservoirs, 
due to they may be modelled in the water resources management model with the same type of element.

As regards to the methodology in the case study, it is based on time series data of precipitation and temperatures from the Spain02 database. The data availability of Spain02 enables obtaining time series of results during the period 1950-2008, being necessary the use of other sources of information in more recent periods. Other key issue is the classification of economic users presented in the SEEAW. In most of River Basin Districts, this information is not available because this information is not specified exhaustively, and it is preferable to classify the economic users in agrarian, urban or industrial users, as presented in the case study. Asset accounts also distinguish between water flows and water in reservoirs. This differentiation is a complex task unless we use simulation models to obtain it.

A priori, among the results obtained, indicators derived from water accounts allow policymakers to compare results between different territories and periods. But, as observed, they are mainly based on the amount of water generated in a territory, with special attention to those resources coming from other territories, but without an in-depth analysis of the amount of water that it is really abstracted. In this sense, WEI and $\mathrm{WCI}$ represent a first approximation to the degree of water stress suffered by the system, despite being based on annual averages and not displaying the seasonality or even a scarcity event at a monthly scale (Pedro-Monzonis et al. (2015b)). The consideration of several scenarios with and without reservoirs, pumping wells, waste water reuse or desalination may be useful for the definition of new indicators related to the stress of a water exploitation system.

It is worth noting that environmental requirements are not explicitly considered in SEEAW tables. In this sense, water abstraction for supplying human populations and economic activities are substantially conditioned, especially in water scarce exploitation systems and/or drought episodes. The introduction of environmental flows in a water resources system may negatively 
affect the existing water uses in the basin and, in those periods when there are not enough water resources, those demands with the lowest priorities will present deficits (PellicerMartínez and Martínez-Paz, 2016). There is a clear need for improving water accounting approaches in order to include environmental requirements. As a first step the use of ESIr has enabled us to obtain a slight understanding of the stress suffered by the river at its mouth area, although results may improve if we analyse ESIr in every surface water body along the river basin. To deal with this issue, we suggest the use of simulation scenarios considering different environmental requirements to compare some of the values obtained in SEEAW tables among other: total abstractions and outflows to the sea.

\section{Conclusions}

As seen, filling SEEAW tables needs a significant degree of knowledge about the temporal and spatial evolution of the different components of the hydrological cycle and the flows between them. The main conclusion obtained from this research is the fact that AQUATOOL DSS is a reliable tool that provides information enough for building physical and use tables and asset accounts under SEEAW methodology, allowing the collection of those parameters of water cycle that cannot be obtained by monitoring. EVALHID module has been used for building physical water balances in natural regime. Moreover, the combined use of SIMGES simulation model and EVALHID allows complete physical water balances in altered flow regime, taking into consideration water allocation demands, evaporation from reservoirs and water transfers among others. In the case of building water accounts were mandatory in the river management plans, it may be desirable to have a standard for SEEAW tables as it exists in other water accounting approaches such as the ISO 14046 on Water Footprint.

In this regard, society expects from policymakers and stakeholders to maximise the profit produced per unit of natural resources. This research pretends to contribute to the objectives of the "Blueprint to safeguard Europe's water resources". It is noteworthy that, in Spain, a large 
part of these methodological decisions are included in the Spanish Guideline of Water Planning (BOE, 2008) with normative status guaranteeing consistency and comparability of the results.

\section{Acknowledgements}

The authors thank two anonymous reviewers for their valuable comments, suggestions and positive feedback. The authors also wish to thank the Water and Environment team of INTECSAINARSA and the Council of Agriculture, Fisheries and Environment of the Regional Government of Andalusia for the data provided in developing this study and the Spanish Ministry of Economy and Competitiveness for its financial support through the NUTEGES project (CGL2012-34978). We also value the support provided by the European Community's Seventh Framework Program in financing the projects ENHANCE (FP7-ENV-2012, 308438), WAMCD (EC-DG Environment No. 07.0329/2013/671291/SUB/ENV.C.1), LIFE ALBUFERA (LIFE12 ENV/ES/000685), IMPREX (H2020WATER-2014-2015, 641811) and Research Group RNM-308 of the Andalusian Government.

\section{References}

Andreu, J., Capilla, J., Sanchis, E., 1996. AQUATOOL, a generalized decision-support system for water resources planning and operational management. J. Hydrol. 177: 269-291. Doi: 10.1016/0022-1694(95)02963-X

Bergström, S. and Forsman, A., 1973. Development of a conceptual deterministic rainfall-runoff model. Nordic Hydrology.

Benavente, J., El Mabrouki, K., García-Aróstegui, J.L., Calabrés, C. and Casas, A., 2005. Uso de técnicas geofísicas para caracterizar la extrusión de agua salina en un acuífero costero mediterráneo bicapa (Río Vélez, provincia de Málaga). Geogaceta 37: 127-130 
BOE (Boletín Oficial del Estado), 2008. Instrucción de Planificación Hidrológica. Ministerio de Medio Ambiente, y Medio Rural y Marino.- 15340 - ORDEN ARM/2656/2008, de 10 de septiembre. Boletín Oficial del Estado 229, 38472-38582.

CIRCABC, 2012. 'Informal meeting of Water and Marine Directors of the European Union, Candidate and EFTA Countries. Copenhagen, 4-5 June 2012. Synthesis', Communication and Information Resource Centre for Administrations, Businesses and Citizens (https://circabc.europa.eu/sd/d/b5d535f4-0df2-4b7b-aa39-

a71483ab8fd4/Synthesis_Water_and_Marine_Directors_Copenhagen.docx) (accessed $07.10 .14)$

Dimova, G., Tzanov, E., Ninov, P., Ribarova, I., Kossida, M., 2014. Complementary use of the WEAP model to underpin the development of SEEAW physical water use and supply tables. 12th International Conference on Computering and Control for the Water Industry, CCWI2013. Procedia Engineering 70: 563-572 doi: 10.1016/j.proeng.2014.02.062

Duan, Q., Sorooshian, S. and Gupta, V., 1992. Effective and efficient global optimization for conceptual rainfall-runoff models. Water Resour. Res., 28 (4), pp. 1015-1031

Dumont, A., Mayor, B. and López-Gunn, E. 2013. Is the rebound effect or Jevons paradox a useful concept for better management of water resources? Insights from the Irrigation Modernisation Process in Spain. Aquatic Procedia, 1, 64-76.

EC (European Commission), 2012. A Blueprint to Safeguard Europe's Water Resources. European Commission, 14.11.2012 COM(2012) 673 final, Brussels.

EC (European Commission), 2015. Guidance document on the application of water balances for supporting the implementation of the WFD. Final - Version 6.1-18/05/2015, Brussels. 
EEA (European Environment Agency), 2005. The European Environment - State and Outlook 2005. European Environmental Agency, Copenhagen.

EEA (European Environment Agency), 2013. Results and lessons from implementing the Water Assets Accounts in the EEA area. From concept to production. EEA Technical report No 7/2013, European Environment Agency, Copenhagen.

EP (European Parliament), 2000. Directive 2000/60/EC of the European Parliament and of the Council of 23 October 2000 establishing a framework for Community action in the field of water policy. Official Journal L 327, 22-12-2000, Brussels.

García-Aróstegui, J.L., Benavente, J., Cruz-San Julián, J.J., 2007. Río Vélez (M.A.S. 060.026). Atlas Hidrogeológico de la provincia de Málaga 2, 185-190. Diputación de Málaga-IGME-UMA

Götzinger, J. and Bárdossy, A., 2007. Comparison of four regionalization methods for a distributed hydrological model. J. Hydrol 333, 374-384

Gutierrez-Martin, C. and Gomez, G. 2011. Assessing irrigation efficiency improvements by using a preference revelation model, Spanish Journal of Agricultural Research 9, 1009-1020.

Hargreaves, G.H. and Samani, Z.A., 1985. Reference crop evapotranspiration from temperature. Applied Eng. in Agric., 1(2): 96-99.

Herrera, S., Gutiérrez, J.M., Ancell, R., Pons, M.R., Frías, M.D., Fernández, J., 2012. Development and analysis for a 50-year high-resolution daily gridded precipitation data set over Spain (Spain02). International Journal of Climatology.

Hunink, J., 2014. La contabilidad de agua: el siguiente reto en la planificación hidrológica de España, iAgua, Apr. 2014 (http://www.iagua.es/blogs/johannes-hunink/la-contabilidad-deagua-el-siguiente-reto-en-la-planificacion-hidrologica-de-espana) Accesed 8 July 2014. 
Lentini, A., Kohfahl, C., Benavente, J., Garacía-Aróstegui, J.L., Vadillo, I., Meyer, H., Pekdeger, A., 2009. The impact of hydrological conditions on salinisation and nitrate concentration in the coastal Velez River aquifer (southern Spain). Environmental Geology, 58: 1785-1795.

MMA (Ministerio de Medio Ambiente), 2000. White paper on water in Spain. Madrid.

Molden, D. and Sakthivadivel, R., 1999. Water Accounting to Assess Use and Productivity of Water, International Journal of Water Resources Development, 15:1-2, 55-71, DOI: $10.1080 / 07900629948934$

Momblanch, A., Andreu, J., Paredes-Arquiola, J., Solera, A. and Pedro-Monzonis, M., 2014. Adapting water accounting for integrated water resource management. The Jucar Water Resource System (Spain) J. Hydrol 519: 3369-3385, doi: http://dx.doi.org/10.1016/j.jhydrol.2014.10.002

Paredes-Arquiola, J., Solera, A., Andreu, J., Lerma, N., 2012. Manual técnico de la herramienta EVALHID para la evaluación de recursos hídricos. Grupo de Ingeniería de Recursos Hídricos. Universitat Politècnica de València.

Pedro-Monzonís, M., Ferrer, J., Solera, A., Estrela, T., Paredes-Arquiola, J., 2015a. Key issues for determining the exploitable water resources in a Mediterranean river basin. Sci Total Environ 503-504: 319-328. http://dx.doi.org/10.1016/i.scitotenv.2014.07.042

Pedro-Monzonís, M., Solera, A., Ferrer, J., Estrela, T., and Paredes-Arquiola, J., 2015b. A review of water scarcity and drought indexes in water resources planning and management. J. Hydrol 527 (2015) 482-493, http://dx.doi.org/10.1016/j.jhydrol.2015.05.003 
Pellicer-Martínez, F. and Martínez-Paz, J.M., 2016. Grey water footprint assessment at the river basin level: Accounting method and case study in the Segura River Basin, Spain. Ecol. Indic. 60, 1173-1183 http://dx.doi.org/10.1016/j.ecolind.2015.08.032

Reilly, T.E., Franke, O.L., Bennett, G.D., 1984. The principle of superposition and its application in ground-water hydraulics. U.S. Geological Survey open-file report ; 84-459.

Ruiz, J.M., 1998. Desarrollo de un modelo hidrológico conceptual-distribuido de simulación continua integrado con un sistema de información geográfica. Tesis Doctoral. Escuela Técnica Superior de Ingeniería de Caminos, Canales y Puertos. Universitat Politècnica de València.

Solera, A., Paredes-Arquiola, J., Andreu, J., 2010. Componentes de un sistema de recursos hidráulicos. Modelos de uso conjunto de aguas superficiales y subterráneas. Madrid: Instituto Geológico y Minero de España 978-84-7840-852-8; pp. 87-110.

Tilmant, A., Marques, G., Mohamed, Y., 2015. A dynamic water accounting framework based on marginal resource opportunity cost. Hydrol. Earth Syst. Sci. Discuss., 19, 1457-1467, doi:10.5194/hessd-11-11735-2014

United Nations, UN, 2008. International Standard Industrial Classification of All Economic Activities (ISIC), Rev 4, Statistical Papers, Series M, No. 4, Rev 4 (United Nations publication, Sales No. E.08.XVII.25) New York, 2008.

United Nations Statistic Division, UNDS, 2012. System of Environmental-Economic Accounting for Water. United Nations, Department of Economic and Social Affairs, Statistics Division, (United Nations publication, Sales No. E.11.XVII.12) New York, 2012. 
Vangelis, H., Tigkas, D. and Tsakiris, G., 2013. The effect of PET method on Reconnaissance Drought Index (RDI) calculation. Journal of Arid Environments, doi: http://dx.doi.org/10.1016/i.jaridenv.2012.07.020 (in press)

Vardon, M., Lenzen, M., Peevor, S. and Creaser, M., 2007. Water accounting in Australia, Ecological Economics, 61, pp. 650-659.

Ward, F. A. and Pulido-Velázquez, M. 2008. Water conservation in irrigation can increase water use. Proceedings of the National Academy of Sciences, 105, 18215-18220. 